\title{
1 "Insulin-like" effects of palmitate might contribute to 2 the development of insulin resistance in hypothalamic neurons
}

\author{
Martin Benzler ${ }^{1}$, Jonas Benzler ${ }^{1}$, Sigrid Stoehr ${ }^{1}$, Cindy Hempp ${ }^{1}$, Mohammed Z. Rizwan ${ }^{2}$, Phil \\ Heyward ${ }^{3}$ and Alexander Tups $1,2, *$ \\ 1 Department of Animal Physiology, Faculty of Biology, Philipps University Marburg, Marburg, Germany; \\ martinbenzler@web.de, jonas.benzler@gmx.de, stoehrs@biologie.uni-marburg.de, chempp@web.de \\ 2 Centre for Neuroendocrinology and Brain Health Research Centre, Department of Physiology, School of \\ Medical Sciences, University of Otago, Dunedin 9054, New Zealand; alexander.tups@otago, \\ mohammed.rizwan@otago.ac.nz \\ 3 Brain Health Research Centre, Department of Physiology, School of Medical Sciences, University of \\ Otago, Dunedin 9054, New Zealand; phil.heyward@otago.ac.nz \\ * Correspondence: alexander.tups@otago.ac.nz; +64-34794862
}

\begin{abstract}
Saturated fatty acids are implicated in the development of metabolic diseases, including obesity and type 2 diabetes. There is evidence, however, that polyunsaturated fatty acids can counteract the pathogenic effects of saturated fatty acids. To gain insight into the early molecular mechanisms by which fatty acids influence hypothalamic inflammation and insulin resistance, we performed time-course experiments in a hypothalamic cell line, using different durations of treatment with the saturated fatty acid palmitate, and the omega-3 polyunsaturated fatty acid, docosahexaenoic acid (DHA). Western blot analysis revealed that palmitate elevated the protein levels of phospho(p)AKT in a time-dependent manner. This effect seems involved in the pathogenicity of palmitate, as temporary inhibition of the PI3K/AKT pathway by selective PI3K inhibitors prevented palmitate-induced insulin resistance. Similarly to palmitate, DHA also increased levels of pAKT, but to a weaker extent. Co-administration of DHA with palmitate decreased pAKT close to the basal level after $8 \mathrm{~h}$, and prevented palmitate-induced insulin resistance after $12 \mathrm{~h}$. Measurement of the inflammatory markers pJNK and pNFkB-p65 revealed tonic elevation of both markers in the presence of palmitate alone. DHA alone transiently induced elevation of pJNK, returning to basal levels by $12 \mathrm{~h}$ treatment. Co-administration of DHA with palmitate prevented palmitate-induced inflammation after $12 \mathrm{~h}$, but not at earlier time points.
\end{abstract}

Keywords: hypothalamus; insulin resistance; inflammation; docosahexaenoic acid; PI3K inhibitor, AKT

\section{Introduction}

Obesity has risen to a global problem occurring in not only developed, but also in emerging nations [1]. A major factor in the development of obesity is over-nutrition, especially the consumption of large amounts of dietary saturated fatty acids (SFA). Obesity in turn enhances the risk for cardiovascular and metabolic diseases, such as type 2 diabetes [2]. In general, food intake and energy expenditure are tightly controlled by a complex interplay between the periphery and the central nervous system (CNS) [3]. Within the CNS this control is mainly exerted by the hypothalamus. A key player in the regulation of whole body energy homeostasis is the arcuate nucleus (ARC), located in the mediobasal hypothalamus adjacent to the median eminence and third ventricle. Among other cell types, there are two predominant neuronal cell populations in the ARC, namely the anorexigenic proopiomelanocortin (POMC)/cocaine- and amphetamine-regulated transcript (CART) co-expressing neurons and the orexigenic neuropeptide $\mathrm{Y}(\mathrm{NPY}) /$ agouti-related peptide $(\mathrm{AgRP}) / \gamma$-aminobutyric acid (GABA) co-expressing neurons. While the POMC/CART neurons are largely responsible for 
mediating inhibition of food intake, the NPY/AgRP/GABA neurons mostly control the stimulation of food intake [3]. During obesity-associated type 2 diabetes, this tightly regulated system is disturbed. Among other markers, type 2 diabetes is characterized by elevated levels of circulating free saturated fatty acids (SFFAs), chronic inflammation and insulin resistance in the periphery and in the hypothalamus [4]. Evidence from animal and cell culture experiments strongly suggests that SFFAs are involved in the development of chronic inflammation and insulin resistance in the ARC, disrupting the regulation of whole-body energy homeostasis.

In rodents obesity causes hypothalamic inflammation (involving the c-Jun NH2-terminal kinase

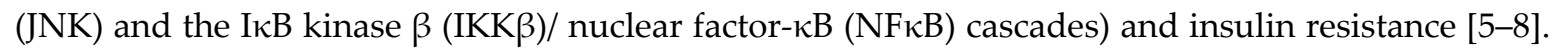
Inhibition of these pro-inflammatory pathways overcomes high-fat diet (HFD)-induced insulin resistance, indicating that inflammation is involved in the development of insulin resistance $[5,9,10]$. A milestone study by Thaler $e$ al . demonstrated that HFD induces an inflammatory response in the rat hypothalamus in a time-dependent manner, followed by neuronal injury [11]. This hypothalamic inflammation response, evident by an increase in the expression of the inflammatory markers, tumor necrosis factor alpha $(\mathrm{TNF} \alpha)$, inhibitor of nuclear factor kappa-B kinase subunit beta (I $\kappa b \kappa b)$ and interleukin-1 $\beta$ (Il-1 $\beta$ ), occurred promptly within $24 \mathrm{~h}$ of feeding HFD. Interestingly, this initial inflammatory response was transient, lasting for 1-3 days, but returned to baseline after 7 days of continued HFD. This phenomenon of distinct phases in regard to HFD-induced inflammation is further corroborated by a recent study in the periphery [12].

The predominant fatty acid in a typical Western style HFD is the saturated fatty acid palmitate, prompting interest in this fatty acid as a potential key element in HFD-induced inflammation and insulin resistance. Posey et al. have reported that intracerebroventricular (icv) injection of palmitate induced hypothalamic inflammation and insulin resistance in rats [5]. In contrast, there is evidence from animal models that monounsaturated fatty acids (MUFAs) and polyunsaturated fatty acids (PUFAs) can counteract the negative effects of saturated fatty acids [13,14]. Belsham et al. showed that palmitate induces insulin resistance in a NPY/AgRP expressing hypothalamic cell line after $24 \mathrm{~h}$ of treatment, and that the palmitate-induced insulin resistance could be abrogated by activation of the adenosine $5^{\prime}$ monophosphate-activated protein kinase (AMPK) [15]. In another study the same group demonstrated that pretreating these cells prior to TNF $\alpha$ stimulation with the PUFA docosahexaenoic acid (DHA) had anti-inflammatory effects, mediated by the G-protein coupled receptor 120 (GPR120) [16]. Several studies using other neuronal or peripherally-derived cell models also indicate counteracting effects of saturated- and mono- or polyunsaturated fatty acids; For instance, several studies in $\mathrm{C} 2 \mathrm{C} 12$ muscle cells revealed that the polyunsaturated fatty acids for example, DHA and eicosapentaenoic acid (EPA) opposed palmitate-induced inflammation and insulin resistance in C2C12 muscle cells [17-21], and the MUFA oleate prevented palmitate-induced inflammation and insulin resistance in N2a neuronal cells [22].

In the present study, we utilized the AgRP-expressing murine hypothalamic cell line mHypoA$2 / 30$ to gain insights into the early influences of fatty acids on hypothalamic inflammation and insulin resistance, by conducting time-course experiments. We observed that the palmitate-induced increase of the inflammatory markers pJNK and pNFkB-p65 occurred prior to the development of palmitateinduced insulin resistance. Interestingly, we found that palmitate itself is able to moderately activate the PI3K/AKT pathway, prompting us to temporarily inhibit this pathway using p110alpha and p110beta PI3K isoform selective inhibitors. We found that palmitate-induced insulin resistance was abrogated by this temporary inhibition of PI3K. Testing the protective effect of DHA against palmitate-induced inflammation and insulin resistance revealed that DHA was able to prevent palmitate-induced inflammation, and insulin resistance. Surprisingly, DHA showed opposing effects at different time points. While DHA showed no effect on palmitate-induced increase of pNFkB-p65 at early phases, DHA itself elevated the protein levels of pJNK as well as of pAKT early in the timecourse, but prevented palmitate-induced increase of pJNK, pNFkB-p65 and pAKT later in the timecourse. 


\section{Materials and Methods}

\subsection{Cell culture maintenance and treatment}

The immortalized adult mouse hypothalamic cell line mHypoA-2/30 (CELLutions-Cedarlane, Burlington ON CAN) was maintained in pyruvate-free, low carb Dulbecco's modified Eagle's medium (DMEM; Invitrogen, Carlsbad CA USA) supplemented with $10 \%$ fetal bovine serum (FBS) and $1 \%$ antibiotic cocktail (penicillin and streptomycin) at $37{ }^{\circ} \mathrm{C}$ with $5 \% \mathrm{CO}_{2}$. For the treatment with fatty acids, mHypoA-2/30 cells were seeded $24 \mathrm{~h}$ before treatment and afterwards treated with either $200 \mu \mathrm{M}$ fatty acid solution or with $10 \%$ fatty acid-free bovine serum albumin (BSA) vehicle for 4, 6, 8, or 12 hours. Two hours before cell lysis, the medium was exchanged for FBS-free, pyruvate-free, low carb DMEM containing the same fatty acid or BSA concentrations as used during treatment. For some experiments, insulin sensitivity was determined by the addition of $10 \mathrm{nM}$ insulin (Sigma-Aldrich, St Louis, MO USA ) 30 minutes before cell lysis.

For experiments involving PI3K inhibition using the selective PI3K inhibitors PIK-75 and TGX221, the cells received a combination of $0.3 \mu \mathrm{M}$ or $1 \mu \mathrm{M}$ of both inhibitors (from $10 \mathrm{mM}$ stock solution in $100 \%$ dimethyl sulfoxide (DMSO)) together with $200 \mu \mathrm{M}$ palmitate for 10 hours. Control cells received 100\% DMSO and 10\% fatty acid free BSA solution. Two hours before cell lysis the medium was exchanged for serum-free DMEM containing the same fatty acid or BSA concentrations as used during treatment, but without the PI3K inhibitors.

To prepare samples for analysis, the cells were washed once with cold phosphate buffered saline (PBS), followed by lysis of the cells via lysis buffer (RIPA lysis buffer containing $1 \times$ protease inhibitor cocktail; Complete, Roche, Mannheim, Germany), 1 mM Naз $V_{4}$ and 20 mM NaF (Sigma-Aldrich, St Louis, MO USA)).

All experiments were repeated three times independently to obtain biological triplicates for analysis.

\subsection{Fatty acid and PI3K inhibitor preparation}

Sodium palmitate (Sigma-Aldrich, St Louis, MO USA) was initially dissolved in $0.1 \mathrm{M} \mathrm{NaOH}$ (pre-heated to $70^{\circ} \mathrm{C}$ ) to give a final stock solution of $100 \mathrm{mM}$ and stored at $-20^{\circ} \mathrm{C}$. For cell culture experiments the stock solution was mixed with a $10 \%$ fatty acid free BSA solution (pre-heated to $55^{\circ} \mathrm{C}$ ) to a final concentration of $10 \mathrm{mM}$. Similarly, DHA, linoleate and oleate (Sigma-Aldrich, St Louis, MO USA) were mixed with a $10 \%$ fatty acid free BSA solution (pre-heated to $55^{\circ} \mathrm{C}$ ) to a final concentration of $10 \mathrm{mM}$. The PI3K inhibitors PIK-75 and TGX-221 (Cayman Chemical, Ann Arbor, MI, USA) were dissolved in $100 \%$ DMSO to give a final stock solution of $10 \mathrm{mM}$ and stored at $-20^{\circ} \mathrm{C}$.

\subsection{Western blot analysis}

Protein content was determined by bicinchoninic acid assay (Thermo Fisher Scientific, Waltham, MA, USA). $20 \mu \mathrm{g}$ of each protein sample was mixed with Laemmli buffer, heated at $90^{\circ} \mathrm{C}$ for 5 minutes and separated on a $10 \%$ sodium dodecyl sulfate-polyacrylamide gel. Proteins were blotted via semi-dry blotting on a nitrocellulose membrane (Amersham, GE Healthcare Life Science, Chalfont St Giles, UK), followed by blocking of the membrane with Tris-buffered saline with $0.1 \%$ Tween 20 (TBS-T) containing 5\% nonfat dry milk (Allpharm, Messel, Germany) for one hour. The membranes were incubated with the following primary antibodies (Cell Signaling Technology, Danvers, MA, USA) in TBS-T over night at $4^{\circ} \mathrm{C}$ : pAKT (Ser473) (1:1000), total AKT ( 1:000), pNFkB-p65 (Ser536) (1:1000), pJNK (Thr183/Tyr185) (1:1000) and GAPDH (1:10000). The membranes were washed three times for 10 minutes in TBS-T and incubated for $1 \mathrm{~h}$ with horseradish peroxidase (HRP)-conjugated secondary antibody (1:5000) (Cell Signaling Technology, Danvers, MA, USA). After additional 3 washing steps, the membranes were incubated with enhanced chemiluminescence (ECL) solution for 2 minutes and subsequently exposed to X-ray hyperfilms (Fujifilm, Minato, Tokio, Japan). Densitometrical quantification of the proteins was performed by using the software ImageJ (Wayne 
148

149

150

151

152

153

154

155

156

157

158

159

160

161

162

163

164

\section{5}

166

167

168

169

170

171

172

173
Rasband, National Institutes of Health, Bethesda, MD, USA). Relative protein expression was analysed from samples loaded on the same SDS page, or loading controls where used to normalize results, in experiments for which the number of samples exceeded the capacity of a single gel. In each experiment data are expressed relative to control, set as $100 \%$.

\subsection{Cell viability}

mHypoA-2/30 cells were seeded in pyruvate-free, low carb DMEM supplemented with 10\% FBS and $1 \%$ antibiotic cocktail. Cells were treated with either $200 \mu \mathrm{M}$ fatty acid solution or with $10 \%$ fatty acid-free BSA vehicle. Cell viability was monitored by staining the cells with tryptophan blue and counting the cell numbers after $6 \mathrm{~h}$ and $12 \mathrm{~h}$ with a Neubauer chamber.

\subsection{Statistics}

The data are presented as the means \pm SEM of triplicates and differences were considered significant if $\mathrm{p} \leq 0.05$. The data were analyzed via SigmaPlot (Jandel Corporation, Erkrath, Germany) and statistical significance was determined using one-way ANOVA with post hoc test (Holm-Sidak). Where data failed equal variance or normality tests, they were analyzed by one-way ANOVA on ranks followed by Dunn's multiple comparison test.

\section{Results}

\subsection{Palmitate induces insulin resistance in hypothalamic neurons}

There is strong evidence that high circulating levels of saturated free fatty acids are associated with the development of hypothalamic inflammation and insulin resistance. We investigated whether palmitate alters the ability of insulin to increase the protein content of pAKT in mHypoA$2 / 30$ cells. The cells were treated with $200 \mu \mathrm{M}$ palmitate or vehicle for $12 \mathrm{~h}$. Thirty min before cell lysis, insulin signaling via the PI3K/AKT pathway was stimulated by the addition of $10 \mathrm{nM}$ insulin (or vehicle) followed by the detection of pAKT protein level via western blot analysis.

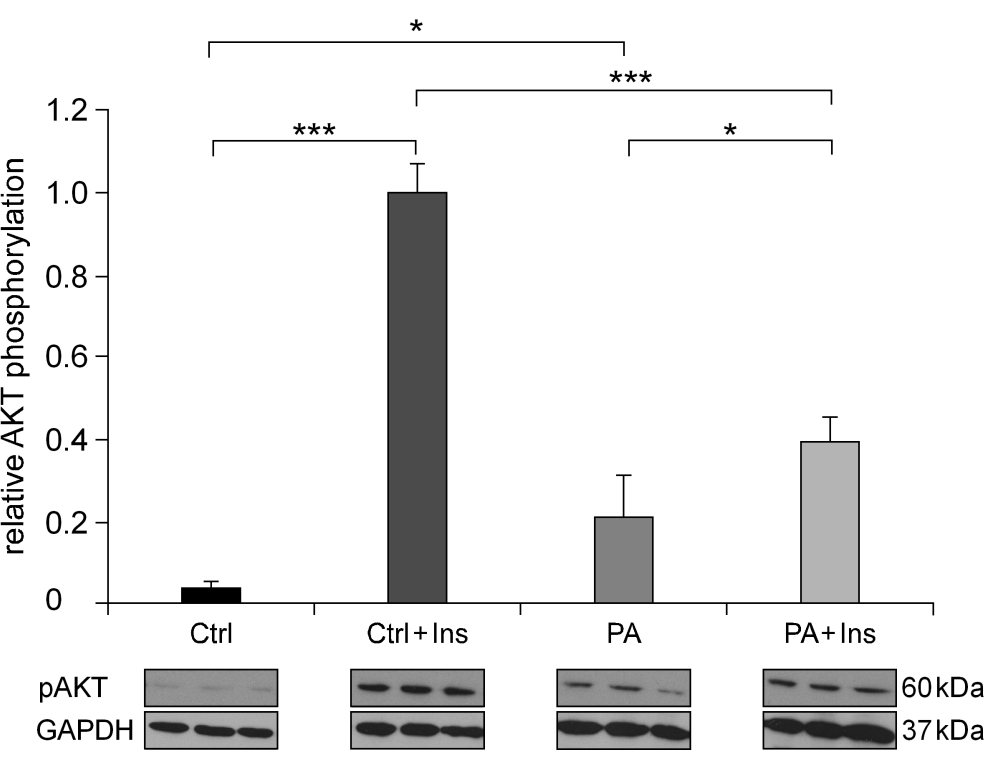

Figure 1: Palmitate induces insulin resistance in mHypoA-2/30 cells within $12 \mathrm{~h}$ of treatment. The effect of palmitate (PA) in the presence or absence of insulin (Ins) on the content of phosphorylated AKT (Ser 473) protein was investigated by western blot analysis. mHypoA-2/30 cells were treated either with vehicle (Ctrl) or with $200 \mu \mathrm{M}$ palmitate for $12 \mathrm{~h}$. Relative levels of pAKT were normalized to each respective GAPDH protein level and the value of vehicle + Ins (Ctrl + Ins) was set to 1. Shown are means \pm SEM of triplicates; ${ }^{*} \mathrm{p} \leq 0.05,{ }^{* * *} \mathrm{p} \leq 0.001$. 
181

182

183

184

185

186

187

188

189

190

191

192

193

194

195

196

197

198

199

While in the absence of insulin, levels of pAKT were at the detection limit of the assay, stimulation of the cells with $10 \mathrm{nM}$ insulin for $30 \mathrm{~min}$ led to an increase of pAKT of about 20 fold ( $\mathrm{p}$ $\leq 0.001$ ) (Figure 1). This insulin-induced increase of pAKT was significantly reduced to about $40 \%$ after treating the cells with $200 \mu \mathrm{M}$ palmitate for $12 \mathrm{~h}(\mathrm{p} \leq 0.001)$. The level of pAKT was moderately increased after $12 \mathrm{~h}$ palmitate treatment without insulin stimulation compared with the corresponding control $(\mathrm{p}=0.04)$ (Figure 1). Determination of cell numbers after $6 \mathrm{~h}$ and $12 \mathrm{~h}$ of treatment with $200 \mu \mathrm{M}$ palmitate revealed no significant differences in cell proliferation in comparison to vehicle treated cells, indicating that treatment of the cells with palmitate did not affect cell growth within $12 \mathrm{~h}$ of treatment $(0 \mathrm{~h}(\ln$ (no. of cells $/ \mathrm{ml}) \pm S E M)$ : vehicle vs palmitate $=10.46 \pm 0.52$ vs $10.46 \pm 0.52 ; 6 \mathrm{~h}(\ln ($ no. of cells $/ \mathrm{ml}) \pm S E M)$ : vehicle vs palmitate $=11.76 \pm 0.24$ vs $11.26 \pm 0.20 ; 12 \mathrm{~h}$ $(\ln ($ no. of cells $/ \mathrm{ml}) \pm S E M)$ : vehicle vs palmitate $=12.10 \pm 0.12$ vs $11.47 \pm 0.60)$.

\subsection{Docosahexaenoic acid and oleate prevent palmitate-induced insulin resistance}

We next investigated the potential of MUFAs or PUFAs to counteract the pathogenic effects of palmitate. We investigated the effects of co-incubation with DHA, the $\omega-6$ polyunsaturated fatty acid linoleate or the $\omega-9$ monounsaturated fatty acid oleate, on palmitate-induced insulin resistance. We incubated mHypoA-2/30 cells either with $200 \mu \mathrm{M}$ of the respective fatty acid alone, or together with $200 \mu \mathrm{M}$ of palmitate for $12 \mathrm{~h}$. Thirty min before the cell lysis, we stimulated the PI3K/AKT pathway with $10 \mathrm{nM}$ insulin. The level of pAKT was detected by western blot analysis. 

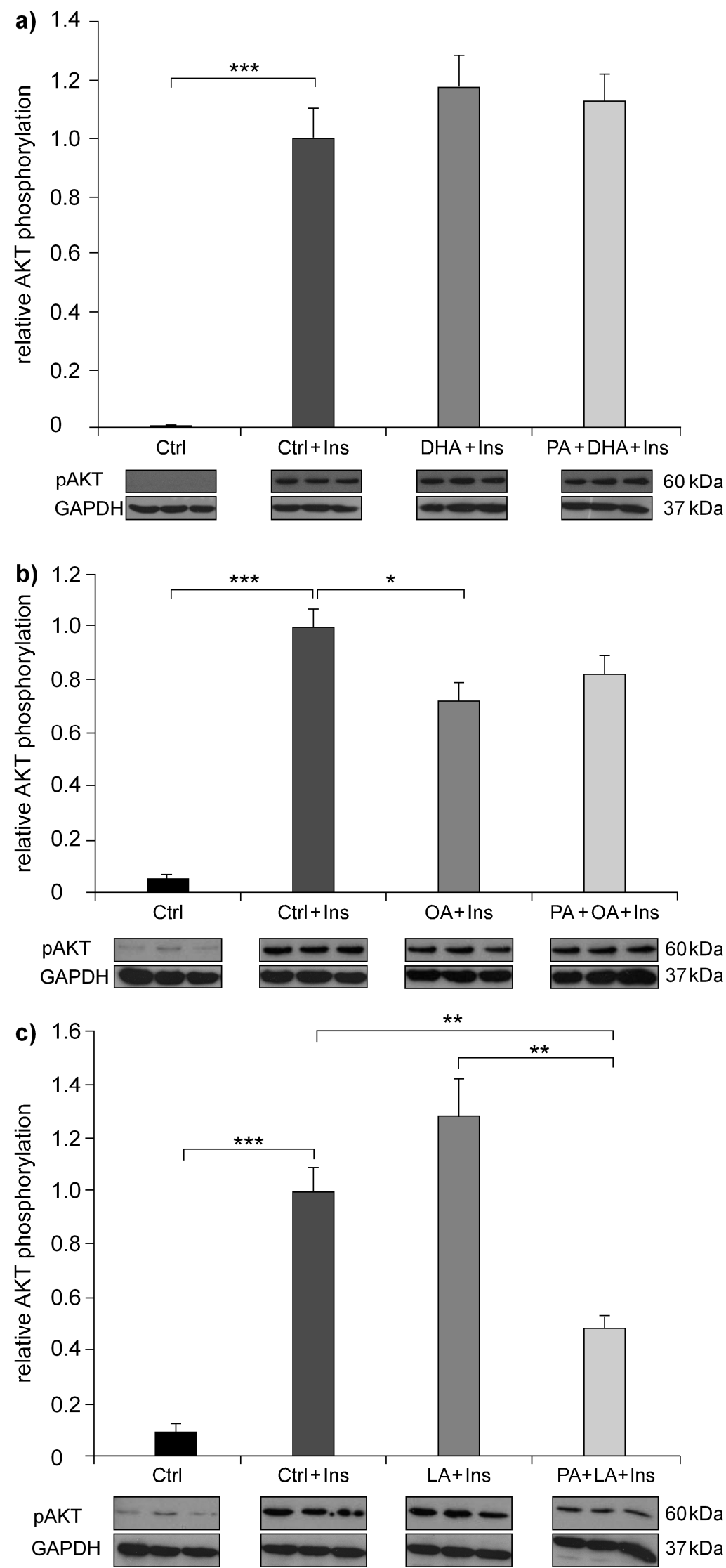

Figure 2: Docosahexaenoic acid and oleate prevent palmitate-induced insulin resistance within $12 \mathrm{~h}$ of treatment. The effect of docosahexaenoic acid (DHA) (a), oleate (OA) (b) and linoleate (LA) (c) on palmitate (PA)-induced insulin resistance was investigated via western blot analysis by measuring the level of pAKT. mHypoA-2/30 cells were treated either with vehicle (Ctrl), with $200 \mu \mathrm{M}$ of the 
respective fatty acid alone or together with $200 \mu \mathrm{M}$ palmitic acid for $12 \mathrm{~h} .30 \mathrm{~min}$ before cell lysis, insulin (Ins) was added to the cells (final conc. $10 \mathrm{nM}$ ). Relative levels of pAKT were normalized to each respective GAPDH protein level and the value of vehicle + Ins (Ctrl + Ins) was set to 1. Shown are means \pm SEM of triplicates; ${ }^{*} \mathrm{p} \leq 0.05,{ }^{* *} \mathrm{p} \leq 0.01,{ }^{* * *} \mathrm{p} \leq 0.001$.

In the presence of $200 \mu \mathrm{M}$ DHA the palmitate-induced insulin resistance was completely abrogated after $12 \mathrm{~h}$ (Figure 2a). A similar effect was seen after co-incubation with $200 \mu \mathrm{M}$ oleate (Figure 2b). Interestingly, treatment with oleate resulted in a slight reduction of pAKT protein levels compared with the insulin treated control $(p=0.041)$. However, co-incubation with linoleate did not prevent palmitate-induced insulin resistance (Figure 2c), showing a level of pAKT comparable to that observed following treatment with palmitate alone (Figure 1).

\subsection{Palmitate induces insulin resistance in hypothalamic neurons in a time-dependent manner}

Based on the finding that palmitate alters the ability of insulin to increase pAKT after $12 \mathrm{~h}$ treatment in the hypothalamic cell line, we investigated the underlying time course. Therefore, neurons were treated with $200 \mu \mathrm{M}$ palmitate or vehicle for $4 \mathrm{~h}, 6 \mathrm{~h}, 8 \mathrm{~h}$ and $12 \mathrm{~h}$. Thirty min before cell lysis, insulin signaling via the PI3K/AKT pathway was stimulated by the addition of $10 \mathrm{nM}$ insulin followed by the detection of PAKT via western blot analysis.

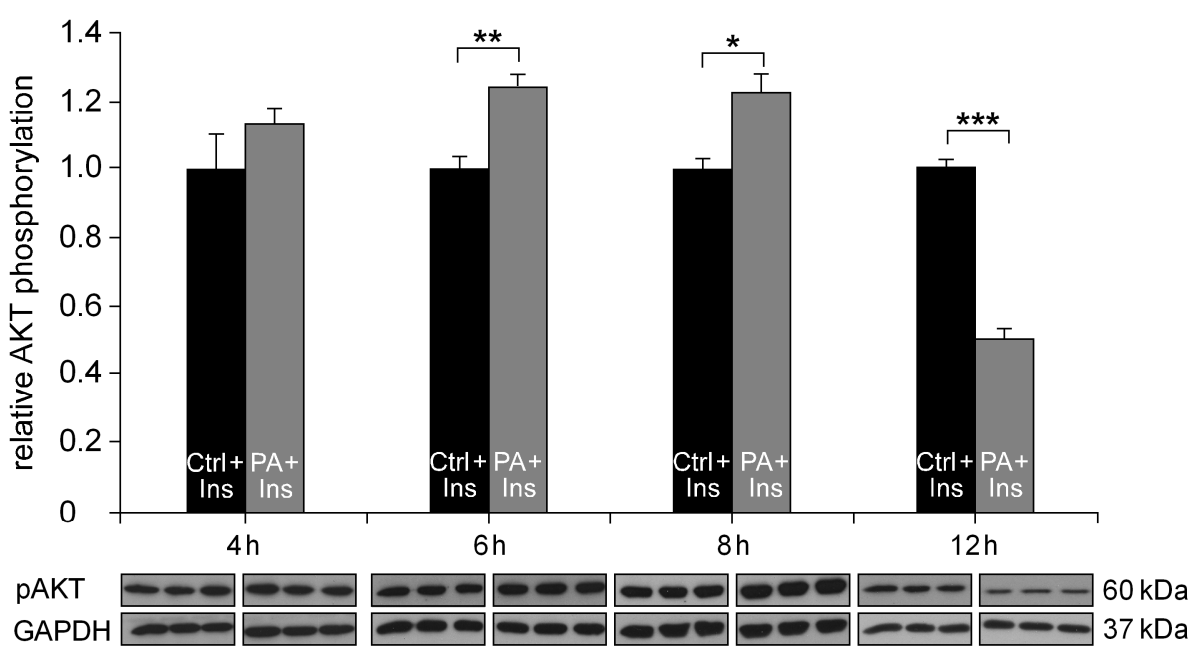

Figure 3: Palmitate-induced insulin resistance takes $12 \mathrm{~h}$ to develop. The effect of different durations of palmitate (PA) treatment on the level of pAKT (Ser473) was investigated by western blot analysis. mHypoA-2/30 cells were either treated with vehicle (Ctrl) or with $200 \mu \mathrm{M}$ palmitate for $4 \mathrm{~h}, 6 \mathrm{~h}, 8 \mathrm{~h}$ or $12 \mathrm{~h}$. Insulin (Ins) was added to the cells (final conc. $10 \mathrm{nM}$ ) $30 \mathrm{~min}$ before cell lysis. Relative levels of pAKT were normalized to each respective GAPDH protein level and the value of vehicle + Ins (Ctrl + Ins) was set to 1 . Shown are means \pm SEM of triplicates; ${ }^{*} \mathrm{p} \leq 0.05,{ }^{* *} \mathrm{p} \leq 0.01,{ }^{* * *} \mathrm{p} \leq 0.001$.

Palmitate induced insulin resistance in a time-dependent manner (Figure 3). While treatment with palmitate did not lead to a decrease of pAKT within the first $8 \mathrm{~h}$, after $12 \mathrm{~h}$ we observed a significant reduction of pAKT to about $50 \%$ in comparison with control $(\mathrm{p} \leq 0.001)$. In contrast, we observed a slight increase of pAKT after palmitate treatment before $12 \mathrm{~h}$, which attained statistical significance after $6 \mathrm{~h}$ and $8 \mathrm{~h}$ of treatment $(\mathrm{p}=0.005$ and $\mathrm{p}=0.018$, respectively).

\subsection{Palmitate increases $p A K T$ in hypothalamic neurons}

We next investigated whether palmitate treatment might alter the level of pAKT in the absence of insulin. To assess whether palmitate is able to directly influence the PI3K/AKT pathway, we treated the cells with $200 \mu \mathrm{M}$ palmitate for $4 \mathrm{~h}, 6 \mathrm{~h}, 8 \mathrm{~h}$ and $12 \mathrm{~h}$, without insulin stimulation. 


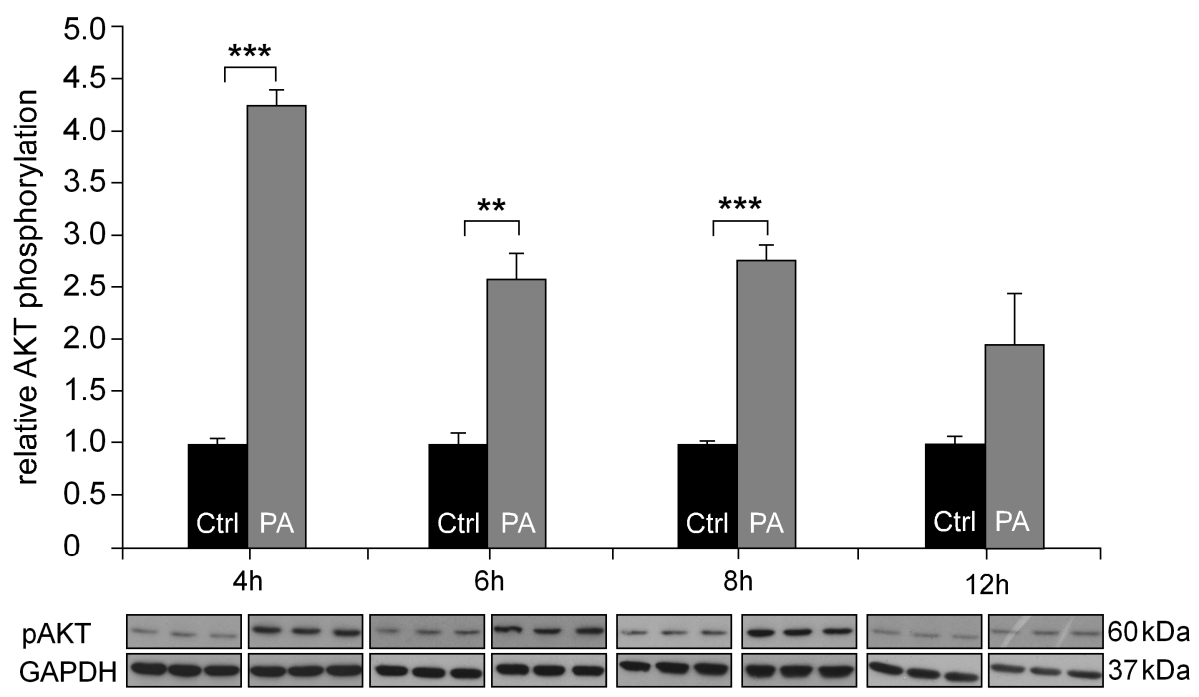

Figure 4: Palmitate increases the level of pAKT. The effect of different durations of palmitate (PA) treatment on the level of pAKT (Ser473) was investigated by western blot analysis. mHypoA-2/30 cells were treated with vehicle (Ctrl) or $200 \mu \mathrm{M}$ palmitate for $4 \mathrm{~h}, 6 \mathrm{~h}, 8 \mathrm{~h}$ or $12 \mathrm{~h}$. Relative levels of pAKT were normalized to each respective GAPDH protein level and the value of vehicle (Ctrl) was set to 1 . Shown are means \pm SEM of triplicates; ${ }^{* *} \mathrm{p} \leq 0.01,{ }^{* * *} \mathrm{p} \leq 0.001$.

Four hours after initiation of treatment, pAKT protein levels were increased by about 4 fold ( $p \leq$ 0.001) (Figure 4). This effect was still visible after $6 \mathrm{~h}$ and $8 \mathrm{~h}$ at a level of about 2.5 fold higher than control levels ( $p=0.004$ and $p \leq 0.001$, respectively). However, there was no significant difference between the control and palmitate treated cells after $12 \mathrm{~h}$. We normalized phosphorylated proteins to the house keeping gene product GAPDH as we consider the signal transduction response to be exclusively dependent on the absolute number of phosphorylated molecules. We further scrutinized that palmitate did not lead to a change in total AKT protein level over the time-course of this experiment (Fig. S1).

\subsection{Docosahexaenoic acid prevents palmitate-induced insulin resistance}

Having established that of the unsaturated fatty acids we tested, DHA had the most profound effect against palmitate-induced insulin resistance, we further investigated this effect of DHA. mHypoA-2/30 cells were treated with $200 \mu \mathrm{M}$ DHA alone or in combination with $200 \mu \mathrm{M}$ palmitate for $4 \mathrm{~h}, 6 \mathrm{~h}, 8 \mathrm{~h}$ or $12 \mathrm{~h}$. Thirty minutes before cell lysis, the PI3K/AKT pathway was stimulated by the addition of $10 \mathrm{nM}$ insulin, followed by measuring of pAKT via western blot analysis. 


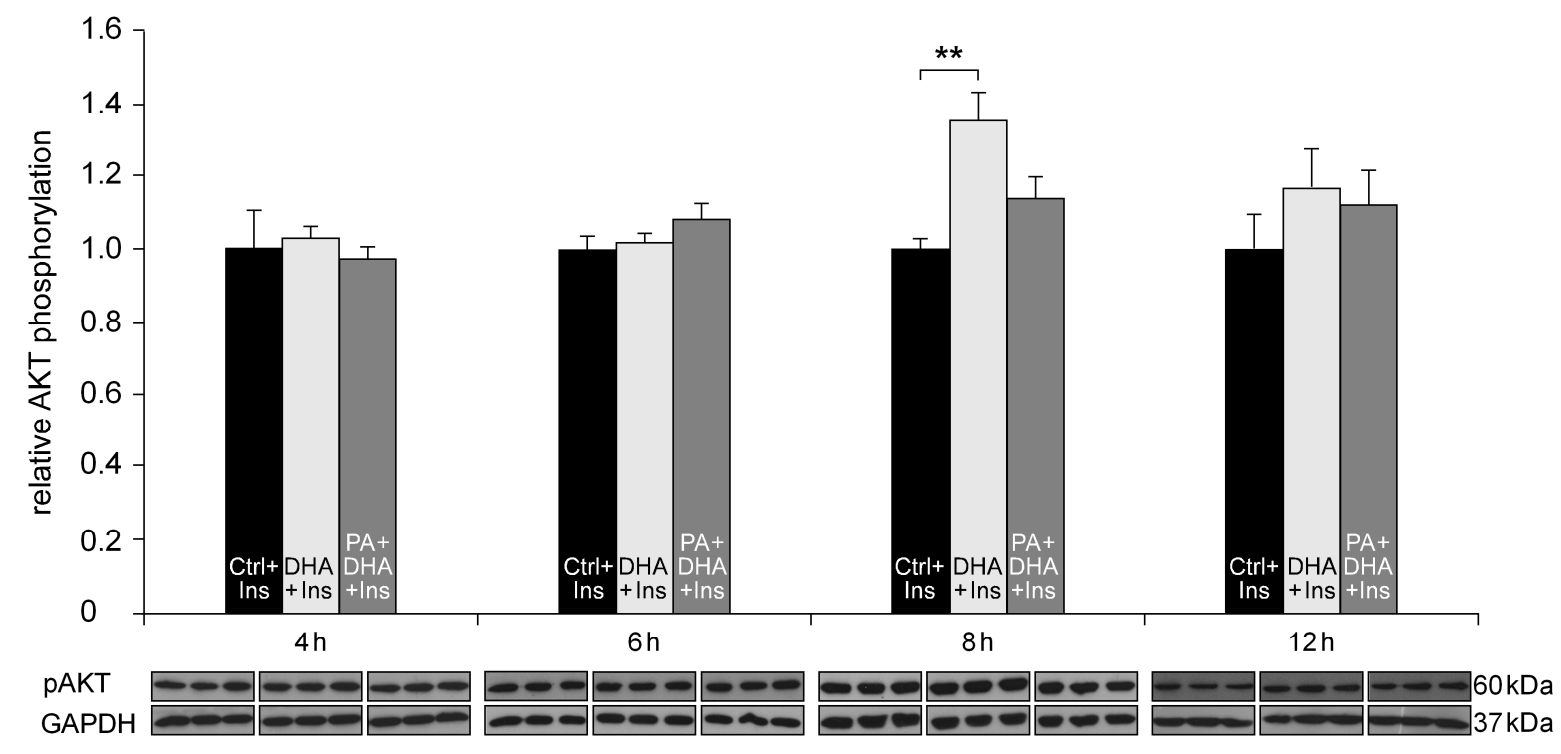

Figure 5: Docosahexaenoic acid prevents palmitate-induced insulin resistance. The effect of docosahexaenoic acid (DHA) on palmitate (PA)-induced insulin resistance was investigated via western blot analysis by measuring pAKT (Ser473) protein levels at different time points. mHypoA2/30 cells were treated either with vehicle (Ctrl), with $200 \mu \mathrm{M}$ DHA alone, or $200 \mu \mathrm{M}$ DHA in combination with $200 \mu \mathrm{M}$ palmitate for $4 \mathrm{~h}, 6 \mathrm{~h}, 8 \mathrm{~h}$ or $12 \mathrm{~h}$. Insulin (Ins) was added to the cells (final conc. $10 \mathrm{nM}$ ), $30 \mathrm{~min}$ before cell lysis. Relative levels of pAKT were normalized to each respective GAPDH protein level and the value for vehicle + Ins (Ctrl + Ins) was set to 1 . Shown are means \pm SEM of triplicates; ${ }^{* *} \mathrm{p} \leq 0.01$.

As expected, treatment with $200 \mu \mathrm{M}$ DHA did not negatively influence the ability of insulin to increase protein levels of pAKT in hypothalamic cells at any measured time point (Figure 5). Furthermore, co-treatment of the cells with $200 \mu \mathrm{M}$ DHA and $200 \mu \mathrm{M}$ palmitate normalized pAKT levels after $12 \mathrm{~h}$, in contrast to the reduced levels observed after treatment with palmitate alone. These findings suggest that DHA is able to prevent palmitate-induced insulin resistance in hypothalamic neurons. A slight increase over control at $8 \mathrm{~h}$ may suggest that DHA enhances the effect of insulin ( $p$ $=0.009)$ at this particular time point.

3.6 DHA increases levels of pAKT protein, in a time-dependent manner similar to palmitate

Based on the unexpected finding that palmitate increased the protein level of pAKT, we further explored whether or not DHA alone influences the level of pAKT, and alters the ability of palmitate to induce pAKT. mHypoA-2/30 cells were treated either with vehicle, or with $200 \mu \mathrm{M}$ DHA alone or in combination with $200 \mu \mathrm{M}$ palmitate for different time periods, without stimulation of the 


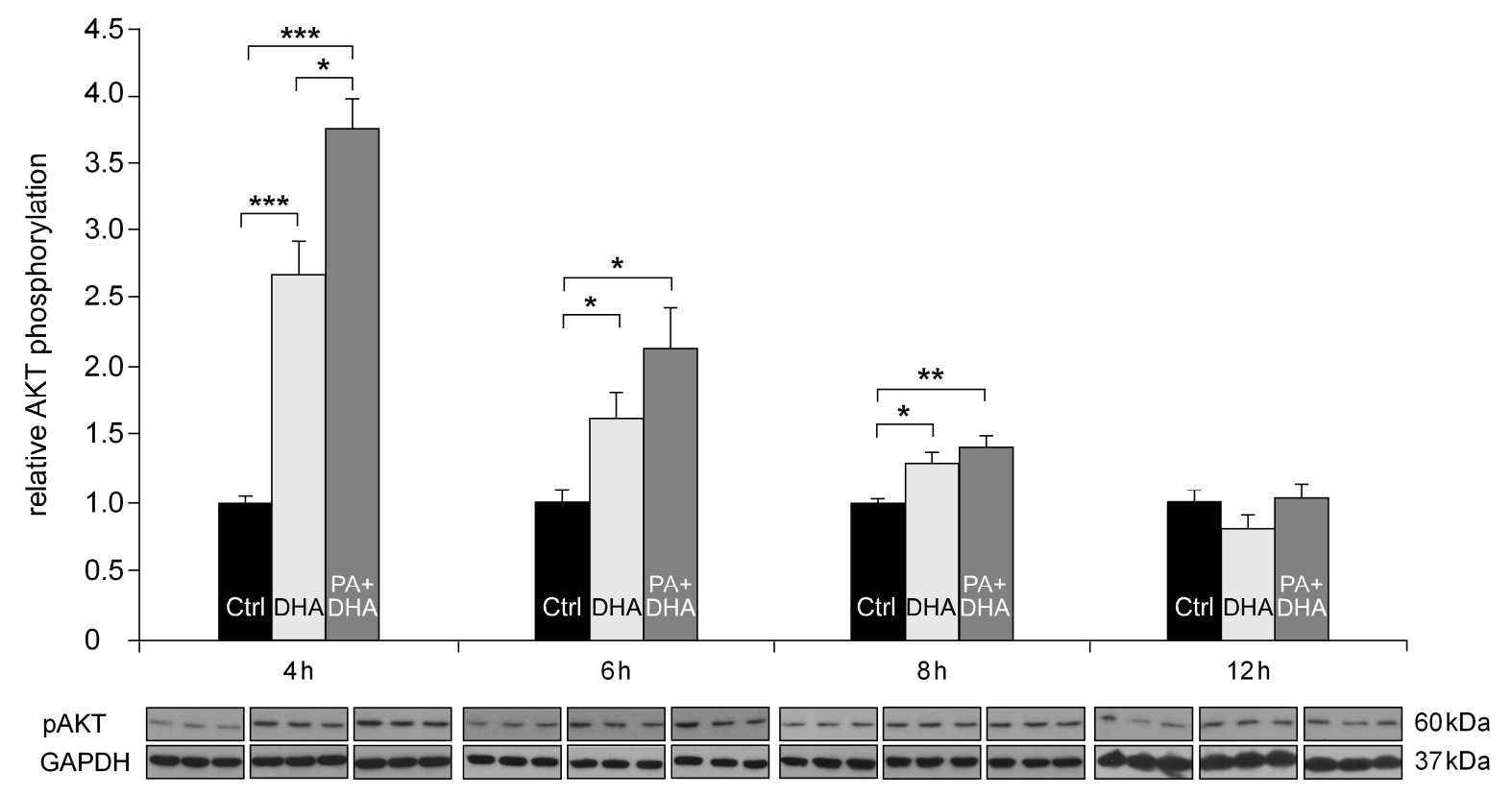

Figure 6: Docosahexaenoic acid increases short-term pAKT protein levels, but prevents the long-term palmitate-induced increase in pAKT. The effect of docosahexaenoic acid (DHA) alone or in combination with palmitate (PA) on pAKT protein levels were analyzed via western blot analysis by measuring protein levels of pAKT (Ser473) at different time points. Therefore, mHypoA-2/30 cells were either treated with vehicle (Ctrl), or with $200 \mu \mathrm{M}$ docosahexaenoic acid alone or in combination with $200 \mu \mathrm{M}$ palmitate for $4 \mathrm{~h}, 6 \mathrm{~h}, 8 \mathrm{~h}$ or $12 \mathrm{~h}$. Relative levels of pAKT were normalized to each respective GAPDH protein level and the value of vehicle (Ctrl) was set to 1 . Shown are means \pm SEM of triplicates; ${ }^{*} \mathrm{p} \leq 0.05,{ }^{* *} \mathrm{p} \leq 0.01,{ }^{* * *} \mathrm{p} \leq 0.001$.

Similar to the effect observed for palmitate, DHA increased pAKT in a time-dependent manner (Figure 6). After $4 \mathrm{~h}$ of treatment, DHA increased pAKT levels by about 2.5 fold $(\mathrm{p}=0.001)$. In combination with palmitate, however, this increase was significantly higher (ca. 4 fold; $p \leq 0.001$ ). After $6 \mathrm{~h}$ of DHA treatment pAKT levels increased about 1.5 fold ( $\mathrm{p}=0.047$ ), whereas after 8 and 12 $\mathrm{h}$ pAKT levels were similar to those in vehicle-treated cells. Palmitate and DHA in combination led to an approximately 2.5 fold increase in levels of pAKT after $6 \mathrm{~h}(\mathrm{p}=0.017)$. After $8 \mathrm{~h}$ treatment with DHA or DHA with palmitate, $\mathrm{pAKT}$ was still slightly elevated relative to control $(\mathrm{p}=0.026$ and $\mathrm{p}=$ $0.009)$, whereas after $12 \mathrm{~h}$ of treatment, neither DHA alone nor DHA with palmitate increased pAKT. As treatment with $200 \mu \mathrm{M}$ palmitate, $200 \mu \mathrm{M}$ DHA did not significantly affect cell proliferation within $12 \mathrm{~h}$ compared with vehicle treated cells $(0 \mathrm{~h}(\ln ($ no. of cells $/ \mathrm{ml}) \pm S E M)$ : vehicle vs palmitate $=10.46 \pm$ 0.52 vs $10.46 \pm 0.52 ; 6 \mathrm{~h}(\ln ($ no. of cells $/ \mathrm{ml}) \pm S E M)$ : vehicle vs palmitate $=11.76 \pm 0.24$ vs $11.47 \pm 0.15$; $12 \mathrm{~h}$ treatment $(\ln ($ no. of cells $/ \mathrm{ml}) \pm S E M)$ : vehicle vs palmitate $=12.10 \pm 0.12$ vs $11.53 \pm 0.59)$.

\subsection{Inhibition of PI3K prevents palmitate-induced insulin resistance}

To test whether or not the palmitate-induced increase of pAKT is involved in palmitate-induced insulin resistance, we temporarily blocked the PI3K/AKT pathway. Temporary inhibition of PI3K was achieved by the use of the PI3K inhibitors PIK-75, a selective inhibitor of the PI3K p110 $\alpha$ catalytic subunit, and TGX-221, a selective inhibitor of the PI3K p110 $\beta$ catalytic subunit. Cells were treated either with $200 \mu \mathrm{M}$ palmitate alone or together with both inhibitors present at $0.3 \mu \mathrm{M}$, or $1 \mu \mathrm{M}$, for $10 \mathrm{~h}$. The medium was then replaced with serum-free medium containing only palmitate but no PI3K inhibitors for additional $2 \mathrm{~h}$, removing the blockade of the PI3K/AKT pathway. Cells were stimulated with $10 \mathrm{nM}$ insulin $30 \mathrm{~min}$ before cell lysis. Levels of pAKT were determined via western blot analysis. 


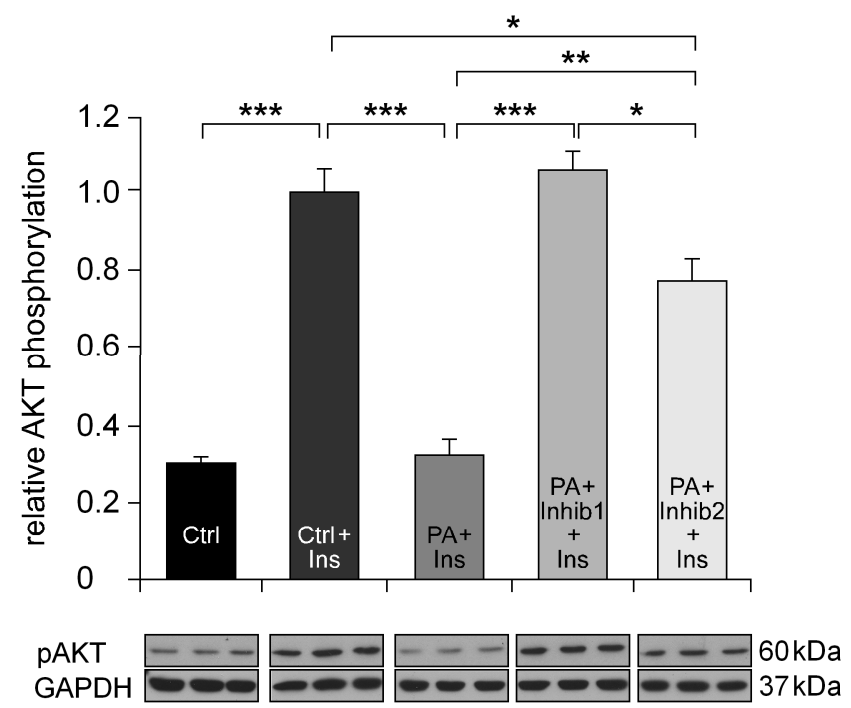

Figure 7: Inhibition of PI3K prevents palmitate-induced insulin resistance. The effect of a combination of the two PI3K inhibitors PIK-75 and TGX-221 on palmitate (PA)-induced insulin resistance was investigated via western blot analysis by measuring the protein level of pAKT (Ser473). mHypoA$2 / 30$ cells were treated either with vehicle (Ctrl), with $200 \mu \mathrm{M}$ palmitate alone, or together with a combination of $0.3 \mu \mathrm{M}$ PIK-75 + $0.3 \mu \mathrm{M}$ TGX-221 (Inhib.1) or $1 \mu \mathrm{M}$ PIK-75 + $1 \mu \mathrm{M}$ TGX-221 (Inhib.2) for $10 \mathrm{~h}$. The medium was then exchanged for additional $2 \mathrm{~h}$ against serum-free medium containing the same fatty acid concentrations, but without the PI3K inhibitors. Insulin (Ins) was added to the cells (final conc. $10 \mathrm{nM}$ ), $30 \mathrm{~min}$ before cell lysis. Relative levels of pAKT were normalized to each respective GAPDH protein level and the value of vehicle + Ins (Ctrl + Ins) was set to 1 . Shown are means \pm SEM of triplicates; ${ }^{*} \mathrm{p} \leq 0.05,{ }^{* *} \mathrm{p} \leq 0.01,{ }^{* * *} \mathrm{p} \leq 0.001$.

PIK-75 and TGX-221 together at either $0.3 \mu \mathrm{M}$ or $1 \mu \mathrm{M}$ abrogated palmitate-induced insulin resistance ( $\mathrm{p} \leq 0.001$ and $\mathrm{p}=0.003$ respectively). The data therefore show that temporary inhibition of the PI3K/AKT pathway can attenuate palmitate-induced insulin resistance (Figure 7). This suggests that that the pathological action of palmitate is related to its ability to increase pAKT protein levels. Interestingly, the use of the higher concentration of inhibitors led to a smaller increase of pAKT by insulin than the lower inhibitor concentration $\operatorname{did}(p=0.017)$. This may reflect ongoing inhibition of the PI3K/AKT pathway, following incubation with the higher inhibitor concentrations.

\subsection{Influence of palmitate and docosahexaenoic acid on early inflammation}

Several studies revealed that palmitate can induce pro-inflammatory signaling in neuronal cells $[15,22,23]$. HFD-induced pro-inflammatory signaling has been shown to occur in different phases [11]. To investigate the early phase of palmitate-induced inflammation and the protective effect of DHA, we treated the cells either with palmitate or DHA alone, or in combination for $8 \mathrm{~h}$ or $12 \mathrm{~h}$. This experiment was done with or without stimulation by insulin. As markers for inflammation, the protein levels of phosphorylated JNK and NFkB-p65 were measured. 
a)

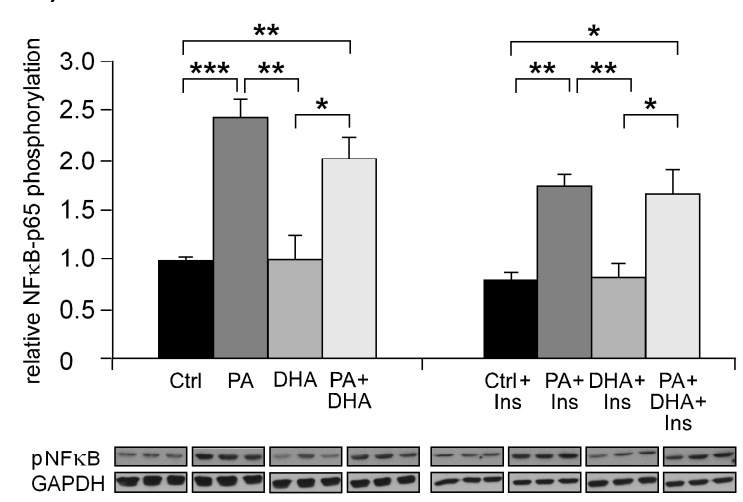

c)

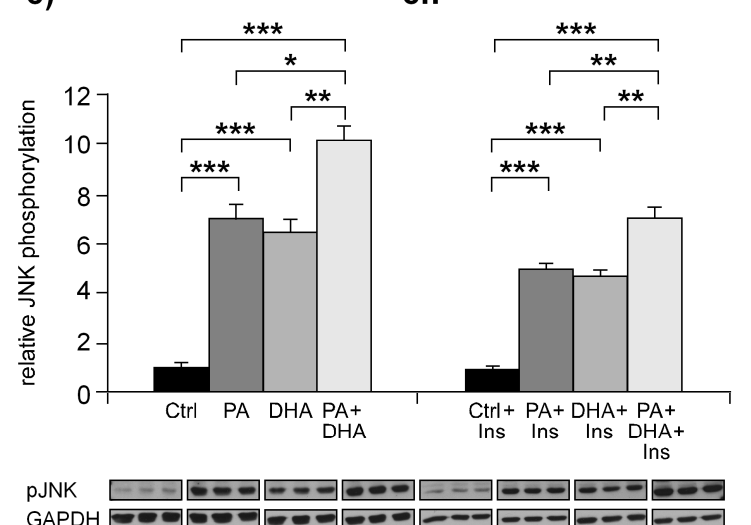

b)

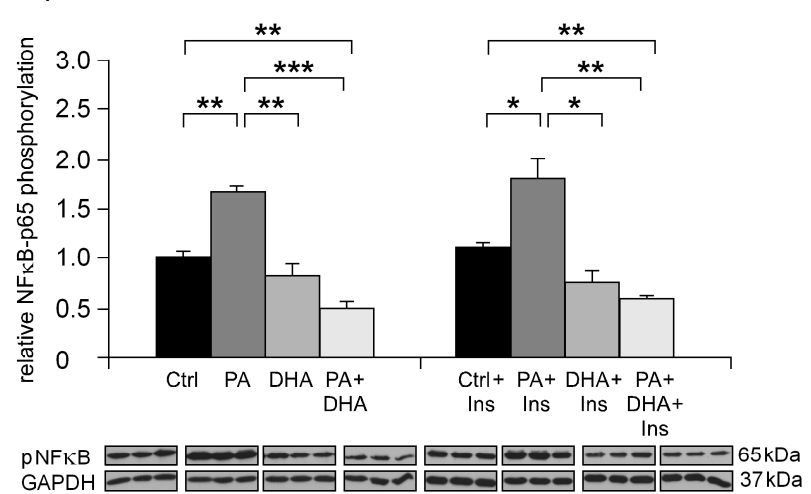

d)

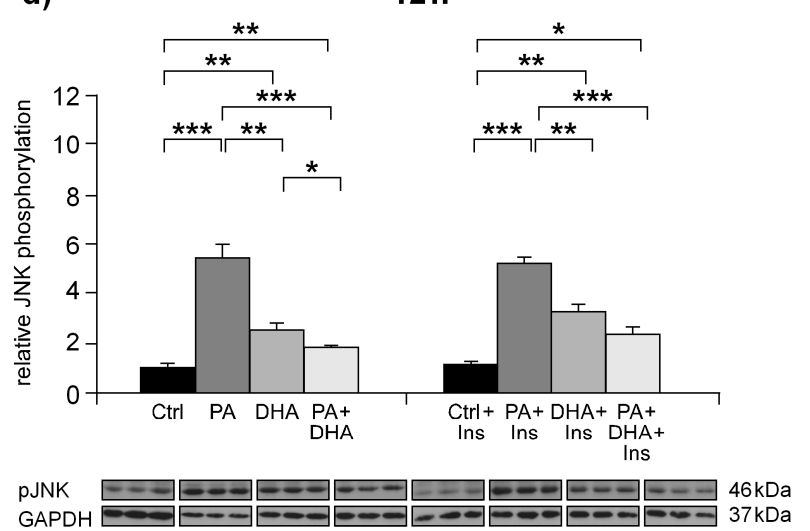

Figure 8: Effects of palmitate and DHA on the protein level of pNFkB-p65 and pJNK after $8 \mathrm{~h}$ and 12 $\mathrm{h}$ of treatment. The effect of palmitate (PA) and DHA on pNFkB-p65 (Ser536) protein levels after $8 \mathrm{~h}$

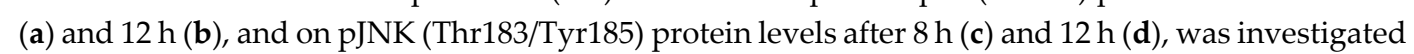
using Western blot analysis. mHypoA-2/30 cells were treated either with vehicle (Ctrl), $200 \mu \mathrm{M}$ palmitate, $200 \mu \mathrm{M}$ DHA, or $200 \mu \mathrm{M}$ of both DHA and palmitate for $8 \mathrm{~h}$ or $12 \mathrm{~h}$. Insulin (Ins, $10 \mathrm{nM}$ ) was added 30 min before cell lysis. Relative levels of pNFkB-p65 and pJNK were normalized to each respective GAPDH protein level and the value of vehicle was set to 1 . Shown are means \pm SEM of triplicates; ${ }^{*} \mathrm{p} \leq 0.05,{ }^{* *} \mathrm{p} \leq 0.01,{ }^{* * *} \mathrm{p} \leq 0.001$.

Palmitate led to an increase in the level of pNFkB-p65 by about 2.5 fold compared with control after $8 \mathrm{~h}$ ( $\mathrm{p} \leq 0.001$, Figure $8 \mathrm{a})$. DHA alone had no effect on pNFkB-p65, and co-incubation of DHA with palmitate did not prevent the palmitate-induced increase in $p N F \kappa B-p 65$ at this time point $(p=$ 0.008 for PA + DHA vs. Ctrl). After $12 \mathrm{~h}$, palmitate was still able to increase levels of pNFkB-p65 (p = 0.002), whereas DHA had no effect (Figure $8 \mathrm{~b}$ ). However, co-administration of DHA and palmitate led to a decrease in levels of pNFkB-p65 to below the levels of control treated cells (PA + DHA vs. PA: $\mathrm{p} \leq 0.001$; PA + DHA vs. Ctrl: $\mathrm{p}=0.007)$. This result suggests that DHA prevents palmitateinduced upregulation of pNFkB-p65.

Levels of pJNK protein were markedly increased (about 6 fold) after $8 \mathrm{~h}$ treatment with either palmitate $(p \leq 0.001)$ or DHA $(p \leq 0.001)$ (Figure $8 \mathrm{c})$. Combined treatment with both fatty acids further increased the levels of $p J N K$ by about 10 fold $(p \leq 0.001)($ PA + DHA vs. PA: $p=0.014 ;$ PA + DHA vs. DHA: $p=0.007)$. After $12 \mathrm{~h}$ of palmitate treatment the level of $\mathrm{pJNK}$ protein was similar to levels observed at $8 \mathrm{~h}$, about 6 fold higher than control $(\mathrm{P} \leq 0.001)$ (Figure $8 \mathrm{~d})$. In the presence of DHA alone levels of pJNK were lower compared to the palmitate treated cells, but did not return to baseline (DHA vs. Ctrl: $\mathrm{p}=0.004$ ). Similar to the results for $\mathrm{pNF} \kappa \mathrm{B}-\mathrm{p} 65$, co-administration of both fatty acids led to a more profound reduction in pJNK, however, levels remained higher than control $(p=0.009)$. This suggests that DHA partially protects from palmitate-induced upregulation of pJNK. 


\section{Discussion}

We used an AgRP expressing hypothalamic cell line to study the time course of fatty acids affecting insulin signaling and inflammatory pathways. Treatment of the cells with $200 \mu \mathrm{M}$ palmitate for $12 \mathrm{~h}$ led to insulin resistance at a molecular level as indicated by a decrease in protein levels of phosphorylated AKT. Co-treatment with DHA or oleate $(200 \mu \mathrm{M})$ prevented palmitate-induced insulin resistance and the time course experiment with DHA revealed that DHA did not negatively affect insulin-induced AKT phosphorylation. The potential prevention of palmitate-induced insulin resistance by oleate has previously been reported in neuroblastoma cells (N2a) and primary rat cortical neurons [22], in which preconditioning the cells with DHA, oleate or linoleate prevented palmitate-induced cytotoxicity. This effect was strongest for preconditioning with oleate, followed by DHA and linoleate. Further observations of a beneficial effect of DHA and oleate against palmitate-induced insulin resistance have come from investigations in peripheral cell models, especially from muscle cells [17-21,24].

We found that $200 \mu \mathrm{M}$ palmitate induced insulin resistance in a time-dependent manner, with reduced insulin responses $12 \mathrm{~h}$ after palmitate treatment. Time-dependent development of palmitateinduced insulin resistance is consistent with observations by Mayer et al. [15], who observed that it required $24 \mathrm{~h}$ of treatment for insulin resistance to develop in a similar hypothalamic cell line, but did not included a $12 \mathrm{~h}$ time-point in their study. They determined insulin resistance by measuring pAKT in relation to total protein (G-protein $\beta$ ). Their western blot showed no alterations of total AKT protein. Furthermore, they found that treatment of the cells for $24 \mathrm{~h}$ with $200 \mu \mathrm{M}$ palmitate did not affect cell morphology as determined by light microscopy, while higher palmitate concentrations showed cytotoxic effects. This finding is in-line with our observation that treatment of the cells for 6 $\mathrm{h}$ or $12 \mathrm{~h}$ with $200 \mu \mathrm{M}$ palmitate had no significant effect on cell proliferation compared with vehicle treated cells. A more recent study in the hypothalamic cell line mHypoA CLU192, using palmitate at $250 \mu \mathrm{M}$, found a $60 \%$ reduction in pAKT at $6 \mathrm{~h}$, increasing to about $80 \%$ reduction at $12 \mathrm{~h}$ and $24 \mathrm{~h}$ [25]. The discrepancy between the studies might be explained by the use of a higher palmitate concentration in the latter study, which might accelerate the development of insulin resistance.

The unexpected observation that palmitate increased pAKT levels independently of insulin suggests that palmitate might activate the PI3K/AKT pathway. It is therefore plausible that activation of this pathway by palmitate might lead to the development of insulin resistance through a negative feedback loop mechanism, the result of which is that insulin is not able to increase pAKT protein levels. Palmitate increased pAKT in a time-dependent manner. To our knowledge, this is the first report of palmitate-induced increase of pAKT in hypothalamic neurons, but time-dependent or transient effects of palmitate have been reported in rodent adipocytes [26,27] and skeletal muscle cells [28]. Pu et al. investigated the acute effects of palmitate on glucose uptake in skeletal muscle tissue and cell lines, and found that palmitate induced translocation of the glucose transporter GLUT4 to the cell membrane via activation of the PI3K/AKT pathway [28]. A transient increase of pAKT began within minutes after treatment, peaked after about $45 \mathrm{~min}$, fell rapidly after $1 \mathrm{~h}$ and was undetectable after $3 \mathrm{~h}$. More consistent with our observations, a transient effect of palmitate on pAKT has been reported in 3T3 L1 adipocytes [29]. Using this cell line, Guo et al. detected a palmitate-induced increase in pAKT after $6 \mathrm{~h}$ of treatment, while this effect was absent after $12 \mathrm{~h}$ and $24 \mathrm{~h}$ [29]. These data indicate that a time-dependent or transient palmitate-induced elevation of pAKT may not be restricted to hypothalamic neurons.

Like palmitate, DHA also increased pAKT protein levels, with the strongest effect detected after $4 \mathrm{~h}$ of treatment. However, the magnitude of increase was lower compared than that following palmitate treatment, and lasted only $6 \mathrm{~h}$ before returning to basal levels. Administration of $200 \mu \mathrm{M}$ DHA together with $200 \mu \mathrm{M}$ palmitate led to an increase of pAKT levels similar to those induced by palmitate alone, at $4 \mathrm{~h}$ and $6 \mathrm{~h}$ after administration, but unlike in the cells treated with palmitate alone, there was almost no difference relative to control after $8 \mathrm{~h}$. These data indicate that DHA is able to increase pAKT independently of palmitate. After $8 \mathrm{~h}$, the presence of DHA may reverse palmitate-induced activation of pAKT, as cells treated with both fatty acids have levels of pAKT similar to controls. This more rapid return to baseline levels may explain the beneficial effects of DHA 
in preventing palmitate-induced insulin resistance. Consistent with this time-dependent effect of DHA, a different study reported that DHA or palmitate increases the expression of gonadotropinreleasing hormone (Gnrh) mRNA through a mechanism dependent on the PI3K signaling pathway [30]. In those studies treatment of the hypothalamic cell line mHypoA-GnRH/GFP with $100 \mu \mathrm{M}$ DHA for $5 \mathrm{~min}$ increased pAKT by about 1.5 fold. Furthermore, inhibition of PI3K via the PI3K inhibitors LY294002 $(50 \mu \mathrm{M})$ or wortmannin $(1 \mu \mathrm{M})$ for $1 \mathrm{~h}$, followed by co-incubation of the cells with either $100 \mathrm{nM}$ DHA or palmitate for $2 \mathrm{~h}$, reduced the effect of both fatty acids on Gnrh mRNA expression. This result indicates that both fatty acids are able to activate the PI3K pathway, and that this activation is involved in the DHA- and palmitate-mediated increase of Gnrh mRNA expression [30]. In another study the same group reported that pretreatment of the hypothalamic cell line rHypoE-7 with $100 \mu \mathrm{M}$ DHA for $1 \mathrm{~h}$ prior to TNF $\alpha$ treatment for $10 \mathrm{~min}$ led to an increase in pAKT protein level of about 3.5 fold [16]. The time-dependent and opposing effects of DHA on pAKT levels and on palmitate-induced elevation of pAKT remain unexplained; further studies are needed to better understand the modulation of the PI3K pathway by DHA.

Our observation that temporary inhibition of the PI3K/AKT pathway via inhibition of PI3K by PIK-75 and TGX-221 prevented palmitate-induced insulin resistance after $12 \mathrm{~h}$ indicates that the effect of palmitate to increase pAKT levels might contribute to the palmitate-induced insulin resistance. A possible explanation for this phenomenon comes from studies of hyperinsulinemia. Several in vivo and in vitro studies have shown that prolonged hyperinsulinemia is correlated with attenuated insulin signaling [31-35]. Using an immortalized hypothalamic cell line, Mayer et al. found that longterm incubation with high concentrations of insulin induced insulin resistance [31]. This hyperinsulinemia-induced insulin resistance was found to be caused by mTOR-S6K1-mediated insulin receptor substrate 1 (IRS-1) phosphorylation at Ser1101, and the reduction of insulin receptor (IR) and IRS-1 protein levels. Since palmitate seems to have "insulin-like" effects, it is therefore possible that palmitate-induced insulin resistance might develop through a mechanism similar to that reported for hyperinsulinemia. A temporary inhibition of the PI3K/AKT pathway might therefore be beneficial to circumvent prolonged activation of this pathway. The mechanism of palmitate-induced insulin resistance, which develops over time, might be interrupted.

Our experiments revealed a protective effect of DHA against palmitate-induced inflammation which was time-dependent. While palmitate increased the level of pNFkB-p65, DHA alone did not. Combined administration of palmitate and DHA required $12 \mathrm{~h}$ of treatment to reverse the effect of palmitate, whereas $8 \mathrm{~h}$ of treatment had no effect. A similar phenomenon was observed for pJNK levels within 12 hours of treatment, but after 8 hours, combined administration of palmitate and DHA increased protein levels of pJNK to levels higher than observed after treatment with either of these fatty acids alone. Nevertheless, our findings suggest that co-treatment with DHA for $12 \mathrm{~h}$ protects against palmitate-induced pro-inflammatory signaling via the NFkB-p65 and JNK pathways.

Some cell culture experiments addressing the influence of fatty acids on hypothalamic inflammation and insulin resistance have been performed. A palmitate-induced increase of $\mathrm{pJNK}$ has been described by Mayer et al. [15]. By treating mHypoE-44 hypothalamic neurons with $200 \mu \mathrm{M}$ palmitate they observed an increase of about 1.5 fold of pJNK protein levels after $4 \mathrm{~h}$ and $24 \mathrm{~h}$ of treatment and an increase of about 3 fold after $8 \mathrm{~h}$ of treatment. Although the authors found inhibition of JNK via the inhibitor SP600125 to be sufficient to prevent palmitate-mediated endoplasmic reticulum (ER) stress, the inhibition failed to prevent palmitate-induced insulin resistance. Interestingly, they neither observed an increase in the protein level of phosphorylated inhibitor of nuclear factor kappa-B kinase subunit beta (pIKK $\beta$ ), a process which occurs prior to the phosphorylation of NFkB-p65 during signal transduction of the NFkB signaling cascade, nor an inhibition of the palmitate-induced insulin resistance after administration of an IKK $\beta$ inhibitor. In another study, the same group investigated the influence of DHA on TNF $\alpha$-induced inflammation in rHypoE-7 hypothalamic neurons [16]. They reported that pretreatment of the cells with $100 \mu \mathrm{M}$ DHA for $1 \mathrm{~h}$ prevented TNF $\alpha$-induced inflammation as examined by several inflammatory markers, including protein levels of pTAK1 or mRNA levels of I $\mathrm{KB} \alpha$. Furthermore, they found the interaction 
479

480

481

482

483

484

485

486

487

488

489

490

491

492

493

494

495

496

497

498

499

500

501

502

503

504

505

506

507

508

509

510

511

512

513

514

515

516

517

518

519

520

521

522

523

of DHA with GPR120 to be responsible for the anti-inflammatory effect of DHA. One study using the neuroblastoma cell line $\mathrm{N} 2 \mathrm{a}$ revealed that $\mathrm{pJNK}$ as well as $\mathrm{pNF} \kappa \mathrm{B}-\mathrm{p} 65$ protein levels were increased with time after exposure of the cells to $300 \mu \mathrm{M}$ palmitate for different time periods between $0 \mathrm{~h}$ and $24 \mathrm{~h}$ [22]. For the time periods of $8 \mathrm{~h}$ and $16 \mathrm{~h}$ of palmitate treatment they observed a 2 to 3 fold increase for the protein levels of pJNK as well as of pNFkB-p65. Pretreatment of the N2a cells with $300 \mu \mathrm{M}$ oleate for $24 \mathrm{~h}$, followed by incubation with $300 \mu \mathrm{M}$ palmitate for another $24 \mathrm{~h}$, revealed a protective effect of oleate against palmitate-induced inflammatory responses, indicated by the complete inhibition of palmitate-induced increase of pERK1/2, pJNK and pNFkB-p65 protein levels.

Taken together, our data confirm the potential of palmitate to induce pro-inflammatory responses, and insulin resistance, in hypothalamic neurons. While other studies have focused on the protective effects of preconditioning with PUFAs and MUFAs against palmitate-induced inflammatory responses, we investigated the effect of co-incubation of palmitate with the PUFA DHA. Similar to the reported effects of preconditioning with DHA or oleate, we observed a protective effect of DHA co-incubation, in palmitate-induced pro-inflammatory responses in hypothalamic neurons. Our unexpected finding that co-incubation with palmitate and DHA showed even lower levels of inflammatory markers than DHA treatment alone, remains to be investigated. Our findings show time-dependence in the development of palmitate-induced hypothalamic inflammation and insulin resistance, and time-dependence in the protective effect of DHA. That DHA itself markedly increased pJNK protein levels after $8 \mathrm{~h}$, but not after $12 \mathrm{~h}$, and was able to reduce the effect of palmitate after $12 \mathrm{~h}$, suggest a bidirectional effect of DHA in early phases of inflammatory response induction.

Our finding that the development of palmitate-induced insulin resistance requires PI3K activation, and that palmitate increased pAKT protein levels in the absence of insulin, suggests that a direct influence of palmitate on the insulin signaling pathway may contribute to the pathogenic influence of palmitate on insulin signaling, and the development of type 2 diabetes.

Acknowledgments: This study was funded by a grant from the German Research Foundation (DFG) and the Royal Society of New Zealand Marsden Fund (both to AT).

Author Contributions: A.T., M.B. and J.B. conceived and designed the experiments and analyzed the data; M.B., M.R., C.H. and S.S. performed the experiments; A.T., M.B. and J.B. wrote the paper. AT provided funding. M.R. and P.H. provided feedback on the manuscript and experimental design.

Conflicts of Interest: The authors declare no conflict of interest.

\section{References}

1. Swinburn, B.A.; Sacks, G.; Hall, K.D.; McPherson, K.; Finegood, D.T.; Moodie, M.L.; Gortmaker, S.L. The global obesity pandemic: Shaped by global drivers and local environments. Lancet 2011, 378, 804-814.

2. Cascio, G.; Schiera, G.; Di Liegro, I. Dietary fatty acids in metabolic syndrome, diabetes and cardiovascular diseases. Curr Diabetes Rev 2012, 8, 2-17.

3. Schwartz, M.W.; Woods, S.C.; Porte, D., Jr.; Seeley, R.J.; Baskin, D.G. Central nervous system control of food intake. Nature 2000, 404, 661-671.

4. Sears, B.; Perry, M. The role of fatty acids in insulin resistance. Lipids Health Dis 2015, 14, 121.

5. Posey, K.A.; Clegg, D.J.; Printz, R.L.; Byun, J.; Morton, G.J.; Vivekanandan-Giri, A.; Pennathur, S.; Baskin, D.G.; Heinecke, J.W.; Woods, S.C., et al. Hypothalamic proinflammatory lipid accumulation, inflammation, and insulin resistance in rats fed a high-fat diet. Am J Physiol Endocrinol Metab 2009, 296, E1003-1012.

6. De Souza, C.T.; Araujo, E.P.; Bordin, S.; Ashimine, R.; Zollner, R.L.; Boschero, A.C.; Saad, M.J.; Velloso, L.A. Consumption of a fat-rich diet activates a proinflammatory response and induces insulin resistance in the hypothalamus. Endocrinology 2005, 146, 4192-4199. 
7. Belgardt, B.F.; Mauer, J.; Wunderlich, F.T.; Ernst, M.B.; Pal, M.; Spohn, G.; Bronneke, H.S.; Brodesser, S.; Hampel, B.; Schauss, A.C., et al. Hypothalamic and pituitary c-jun n-terminal kinase 1 signaling coordinately regulates glucose metabolism. Proc Natl Acad Sci U S A 2010, 107, 6028-6033.

8. Zhang, X.; Zhang, G.; Zhang, H.; Karin, M.; Bai, H.; Cai, D. Hypothalamic ikkbeta/nf-kappab and er stress link overnutrition to energy imbalance and obesity. Cell 2008, 135, 61-73.

9. Benzler, J.; Ganjam, G.K.; Pretz, D.; Oelkrug, R.; Koch, C.E.; Legler, K.; Stohr, S.; Culmsee, C.; Williams, L.M.; Tups, A. Central inhibition of ikkbeta/nf-kappab signaling attenuates high-fat diet-induced obesity and glucose intolerance. Diabetes 2015, 64, 2015-2027.

10. Benzler, J.; Ganjam, G.K.; Legler, K.; Stohr, S.; Kruger, M.; Steger, J.; Tups, A. Acute inhibition of central cjun n-terminal kinase restores hypothalamic insulin signalling and alleviates glucose intolerance in diabetic mice. J Neuroendocrinol 2013, 25, 446-454.

11. Thaler, J.P.; Yi, C.X.; Schur, E.A.; Guyenet, S.J.; Hwang, B.H.; Dietrich, M.O.; Zhao, X.; Sarruf, D.A.; Izgur, V.; Maravilla, K.R., et al. Obesity is associated with hypothalamic injury in rodents and humans. J Clin Invest 2012, 122, 153-162.

12. Williams, L.M.; Campbell, F.M.; Drew, J.E.; Koch, C.; Hoggard, N.; Rees, W.D.; Kamolrat, T.; Thi Ngo, H.; Steffensen, I.L.; Gray, S.R., et al. The development of diet-induced obesity and glucose intolerance in c57bl/6 mice on a high-fat diet consists of distinct phases. PLoS One 2014, 9, e106159.

13. Pimentel, G.D.; Lira, F.S.; Rosa, J.C.; Oller do Nascimento, C.M.; Oyama, L.M.; Harumi Watanabe, R.L.; Ribeiro, E.B. High-fat fish oil diet prevents hypothalamic inflammatory profile in rats. ISRN Inflamm 2013, $2013,419823$.

14. Cintra, D.E.; Ropelle, E.R.; Moraes, J.C.; Pauli, J.R.; Morari, J.; Souza, C.T.; Grimaldi, R.; Stahl, M.; Carvalheira, J.B.; Saad, M.J., et al. Unsaturated fatty acids revert diet-induced hypothalamic inflammation in obesity. PLoS One 2012, 7, e30571.

15. Mayer, C.M.; Belsham, D.D. Palmitate attenuates insulin signaling and induces endoplasmic reticulum stress and apoptosis in hypothalamic neurons: Rescue of resistance and apoptosis through adenosine $5^{\prime}$ monophosphate-activated protein kinase activation. Endocrinology 2010, 151, 576-585.

16. Wellhauser, L.; Belsham, D.D. Activation of the omega-3 fatty acid receptor gpr120 mediates antiinflammatory actions in immortalized hypothalamic neurons. J Neuroinflammation 2014, 11, 60.

17. Chen, S.C.; Chen, P.Y.; Wu, Y.L.; Chen, C.W.; Chen, H.W.; Lii, C.K.; Sun, H.L.; Liu, K.L. Long-chain polyunsaturated fatty acids amend palmitate-induced inflammation and insulin resistance in mouse c2c12 myotubes. Food Funct 2016, 7, 270-278.

18. Pinel, A.; Rigaudiere, J.P.; Laillet, B.; Pouyet, C.; Malpuech-Brugere, C.; Prip-Buus, C.; Morio, B.; Capel, F. $\mathrm{N}$-3pufa differentially modulate palmitate-induced lipotoxicity through alterations of its metabolism in c2c12 muscle cells. Biochim Biophys Acta 2016, 1861, 12-20.

19. Coll, T.; Eyre, E.; Rodriguez-Calvo, R.; Palomer, X.; Sanchez, R.M.; Merlos, M.; Laguna, J.C.; VazquezCarrera, M. Oleate reverses palmitate-induced insulin resistance and inflammation in skeletal muscle cells. J Biol Chem 2008, 283, 11107-11116.

20. Peng, G.; Li, L.; Liu, Y.; Pu, J.; Zhang, S.; Yu, J.; Zhao, J.; Liu, P. Oleate blocks palmitate-induced abnormal lipid distribution, endoplasmic reticulum expansion and stress, and insulin resistance in skeletal muscle. Endocrinology 2011, 152, 2206-2218.

21. Capel, F.; Acquaviva, C.; Pitois, E.; Laillet, B.; Rigaudiere, J.P.; Jouve, C.; Pouyet, C.; Gladine, C.; Comte, B.; Vianey Saban, C., et al. Dha at nutritional doses restores insulin sensitivity in skeletal muscle by preventing lipotoxicity and inflammation. J Nutr Biochem 2015, 26, 949-959. 
22. Kwon, B.; Lee, H.K.; Querfurth, H.W. Oleate prevents palmitate-induced mitochondrial dysfunction, insulin resistance and inflammatory signaling in neuronal cells. Biochim Biophys Acta 2014, 1843, 1402-1413.

23. Morari, J.; Anhe, G.F.; Nascimento, L.F.; de Moura, R.F.; Razolli, D.; Solon, C.; Guadagnini, D.; Souza, G.; Mattos, A.H.; Tobar, N., et al. Fractalkine (cx3cl1) is involved in the early activation of hypothalamic inflammation in experimental obesity. Diabetes 2014, 63, 3770-3784.

24. Kwon, B.; Querfurth, H.W. Palmitate activates mtor/p70s6k through ampk inhibition and hypophosphorylation of raptor in skeletal muscle cells: Reversal by oleate is similar to metformin. Biochimie 2015, 118, 141-150.

25. Diaz, B.; Fuentes-Mera, L.; Tovar, A.; Montiel, T.; Massieu, L.; Martinez-Rodriguez, H.G.; Camacho, A. Saturated lipids decrease mitofusin 2 leading to endoplasmic reticulum stress activation and insulin resistance in hypothalamic cells. Brain Res 2015, 1627, 80-89.

26. Hardy, R.W.; Ladenson, J.H.; Henriksen, E.J.; Holloszy, J.O.; McDonald, J.M. Palmitate stimulates glucose transport in rat adipocytes by a mechanism involving translocation of the insulin sensitive glucose transporter (glut4). Biochem Biophys Res Commun 1991, 177, 343-349.

27. Hunnicutt, J.W.; Hardy, R.W.; Williford, J.; McDonald, J.M. Saturated fatty acid-induced insulin resistance in rat adipocytes. Diabetes 1994, 43, 540-545.

28. Pu, J.; Peng, G.; Li, L.; Na, H.; Liu, Y.; Liu, P. Palmitic acid acutely stimulates glucose uptake via activation of akt and erk1/2 in skeletal muscle cells. J Lipid Res 2011, 52, 1319-1327.

29. Guo, W.; Wong, S.; Xie, W.; Lei, T.; Luo, Z. Palmitate modulates intracellular signaling, induces endoplasmic reticulum stress, and causes apoptosis in mouse $3 \mathrm{t} 3-11$ and rat primary preadipocytes. Am J Physiol Endocrinol Metab 2007, 293, E576-586.

30. Tran, D.Q.; Ramos, E.H.; Belsham, D.D. Induction of gnrh mrna expression by the omega-3 polyunsaturated fatty acid docosahexaenoic acid and the saturated fatty acid palmitate in a gnrhsynthesizing neuronal cell model, mhypoa-gnrh/gfp. Mol Cell Endocrinol 2016, 426, 125-135.

31. Mayer, C.M.; Belsham, D.D. Central insulin signaling is attenuated by long-term insulin exposure via insulin receptor substrate-1 serine phosphorylation, proteasomal degradation, and lysosomal insulin receptor degradation. Endocrinology 2010, 151, 75-84.

32. Gavin, J.R., 3rd; Roth, J.; Neville, D.M., Jr.; de Meyts, P.; Buell, D.N. Insulin-dependent regulation of insulin receptor concentrations: A direct demonstration in cell culture. Proc Natl Acad Sci U S A 1974, 71, 84-88.

33. Martin, C.; Desai, K.S.; Steiner, G. Receptor and postreceptor insulin resistance induced by in vivo hyperinsulinemia. Can J Physiol Pharmacol 1983, 61, 802-807.

34. Rizza, R.A.; Mandarino, L.J.; Genest, J.; Baker, B.A.; Gerich, J.E. Production of insulin resistance by hyperinsulinaemia in man. Diabetologia 1985, 28, 70-75.

35. Nazarians-Armavil, A.; Chalmers, J.A.; Lee, C.B.; Ye, W.; Belsham, D.D. Cellular insulin resistance disrupts hypothalamic mhypoa-pomc/gfp neuronal signaling pathways. J Endocrinol 2014, 220, 13-24. 